Review

\title{
From Lipid Homeostasis to Differentiation: Old and New Functions of the Zinc Cluster Proteins Ecm22, Upc2, Sut1 and Sut2
}

\author{
Ifeoluwapo Matthew Joshua and Thomas Höfken * \\ Division of Biosciences, Brunel University London, Uxbridge UB8 3PH, UK; ifeoluwapo.joshua@brunel.ac.uk \\ * Correspondence: thomas.hoefken@brunel.ac.uk; Tel.: +44-1895-267847
}

Academic Editor: Masatoshi Maki

Received: 28 February 2017; Accepted: 31 March 2017; Published: 5 April 2017

\begin{abstract}
Zinc cluster proteins are a large family of transcriptional regulators with a wide range of biological functions. The zinc cluster proteins Ecm22, Upc2, Sut1 and Sut2 have initially been identified as regulators of sterol import in the budding yeast Saccharomyces cerevisiae. These proteins also control adaptations to anaerobic growth, sterol biosynthesis as well as filamentation and mating. Orthologs of these zinc cluster proteins have been identified in several species of Candida. Upc2 plays a critical role in antifungal resistance in these important human fungal pathogens. Upc2 is therefore an interesting potential target for novel antifungals. In this review we discuss the functions, mode of actions and regulation of Ecm22, Upc2, Sut1 and Sut2 in budding yeast and Candida.
\end{abstract}

Keywords: zinc cluster protein; transcription factor; sterol uptake; sterol biosynthesis; anaerobic; filamentation; mating; budding yeast; Candida; antifungal

\section{Introduction}

$\mathrm{Zn}(\mathrm{II})_{2} \mathrm{Cys}_{6}$ binuclear cluster proteins or just zinc cluster proteins are a large family of exclusively fungal transcriptional regulators [1,2]. The first studied member of this family was Gal4, which is one of the best characterized eukaryotic transcriptional activators. Zinc cluster proteins contain a well-conserved Cys- $X_{2}-$ Cys- $X_{6}-$ Cys- $X_{5-12}-$ Cys- $X_{2}-$ Cys- $X_{6-8}$-Cys motif, which is part of a DNA-binding domain. The three-dimensional structure of $\mathrm{Zn}(\mathrm{II})_{2} \mathrm{Cys}_{6}$ cluster has been determined for several proteins including Gal4 and Ppr1 (Figure 1) [2-4]. In Gal4, Ppr1 and several other proteins, the first three cysteine residues of the motif bind to one $\mathrm{Zn}^{2+}$ ion and the next three cysteines conjugate a second $\mathrm{Zn}^{2+}$ ion. Binding of these zinc ions is necessary to form the compact structure of two short $\alpha$ helices separated by a loop. The $\mathrm{Zn}(\mathrm{II})_{2} \mathrm{Cys}_{6}$ cluster of most if not all members of the family seems to bind directly to DNA. In many proteins, the $\mathrm{Zn}(\mathrm{II})_{2} \mathrm{Cys}_{6}$ cluster is followed by a linker region that is also part of the DNA-binding domain [5] (Figure 1). This linker can be involved in DNA-binding specificity [6]. The Gal4 linker is extended and follows one DNA strand. In contrast, the Ppr1 linker forms an antiparallel $\beta$ sheet and has no contact with DNA. In Gal4, Ppr1 and several other zinc cluster proteins the linker region is connected to a coiled-coil dimerization domain [5] (Figure 1). Some zinc cluster proteins might bind as monomers to DNA but the majority of proteins form dimers. 
A

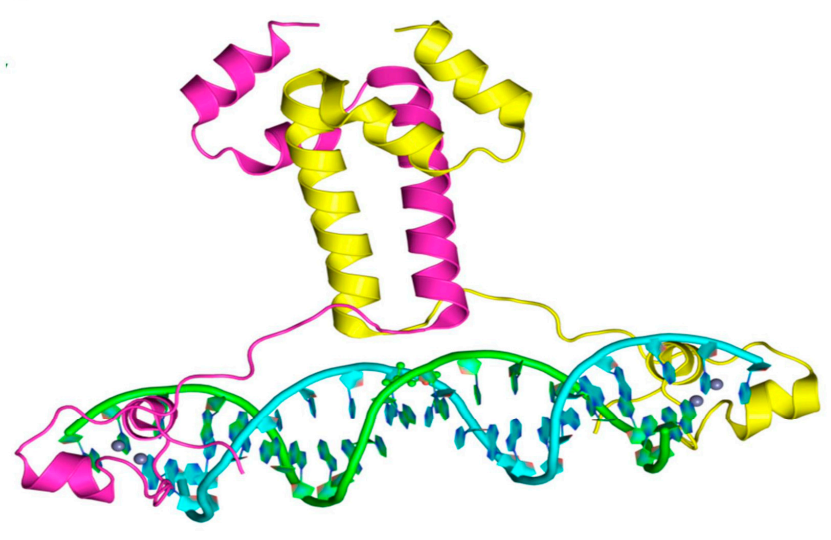

B

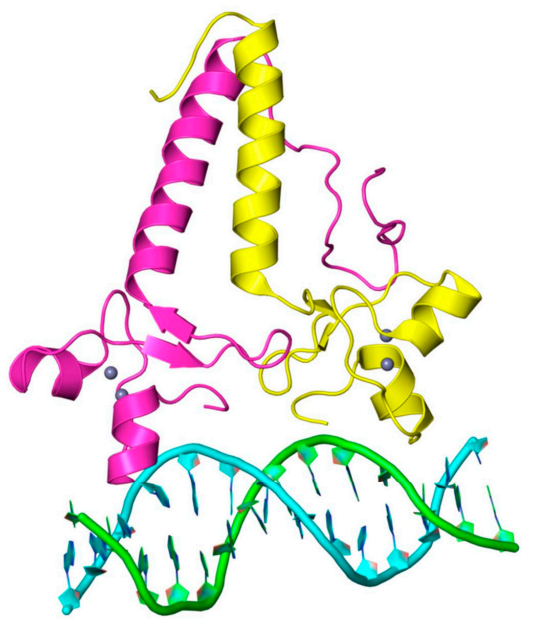

Figure 1. Structures of DNA-binding domains of zinc cluster proteins. (A) Crystal structure of the Gal4-DNA complex (PDB 1D66); and (B) crystal structure of the Ppr1 DNA-binding domain (PDB 1PYI). Both proteins form dimers. The two subunits are shown in yellow and pink. Grey spheres represent $\mathrm{Zn}^{2+}$ ions.

Zinc cluster proteins are best studied in the budding yeast Saccharomyces cerevisiae [2]. Its genome encodes 55 members of this family. Several zinc cluster proteins of the human fungal pathogen Candida albicans have also been well characterized. Sequencing of the genome allowed the identification of 77 putative zinc cluster proteins in this species [2]. Since this family of transcriptional regulators is quite large, it is not surprising that their members are involved in a wide range of functions from amino acid metabolism to multidrug resistance [2]. The zinc cluster proteins Sut1, Sut2, Upc2 and Ecm22 have initially been identified as important regulators of sterol uptake [7-11]. Later it was shown that these proteins also have other functions such as regulation of sterol biosynthesis and more recently differentiation. In this paper we review the functions of these zinc cluster proteins and describe the regulation of their activities. Since Sut1, Sut2, Upc2 and Ecm22 have first been characterized in budding yeast and because much of our understanding of their functions and regulation is largely derived from experiments using budding yeast, we first focus on this species in this review. We then highlight the role of SUT1, SUT2, UPC2 and ECM22 orthologs in the pathogenesis of several Candida species.

Budding yeast SUT1/SUT2 and ECM22/UPC2 are paralogous pairs that probably arose from a whole-genome duplication of a budding yeast ancestor [10-12]. Ecm22 and Upc2 are not closely related to any other zinc cluster protein [13]. They have a perfect zinc cluster motif at the N-terminus as found in almost all zinc cluster proteins [5] (Figure 2). The DNA-binding domains of Ecm22 and Upc2 show some homology with the DNA-binding domain of Ppr1 and Gal4, respectively. Their three-dimensional structure might therefore also be similar (Figure 1).

Sut1/Sut2 are much smaller than Ecm22/Upc2 and the homology is rather low. Sut1 and Sut2 are unique among zinc cluster proteins as they do not have a 5-12 residue spacer in the centre of the $\mathrm{Zn}(\mathrm{II})_{2} \mathrm{Cys}_{6}$ cluster. Instead, the third and fourth cysteine are separated by a much larger spacer of over 60 residues [5,10]. It would therefore be interesting to determine their three-dimensional structure as this might be relevant to their function.

Since Ecm22, Upc2, Sut1 and Sut2 are transcription regulators, it is not surprising that nuclear localization signals (NLSs) have been predicted for all proteins (Figure 2). However, functionality has only been demonstrated for the Upc2 NLS [14]. Sut1 and Sut2 exclusively localize to the nucleus, whereas Ecm22 and Upc2 can shuttle between the cytoplasm and the nucleus [10,14-17]. 

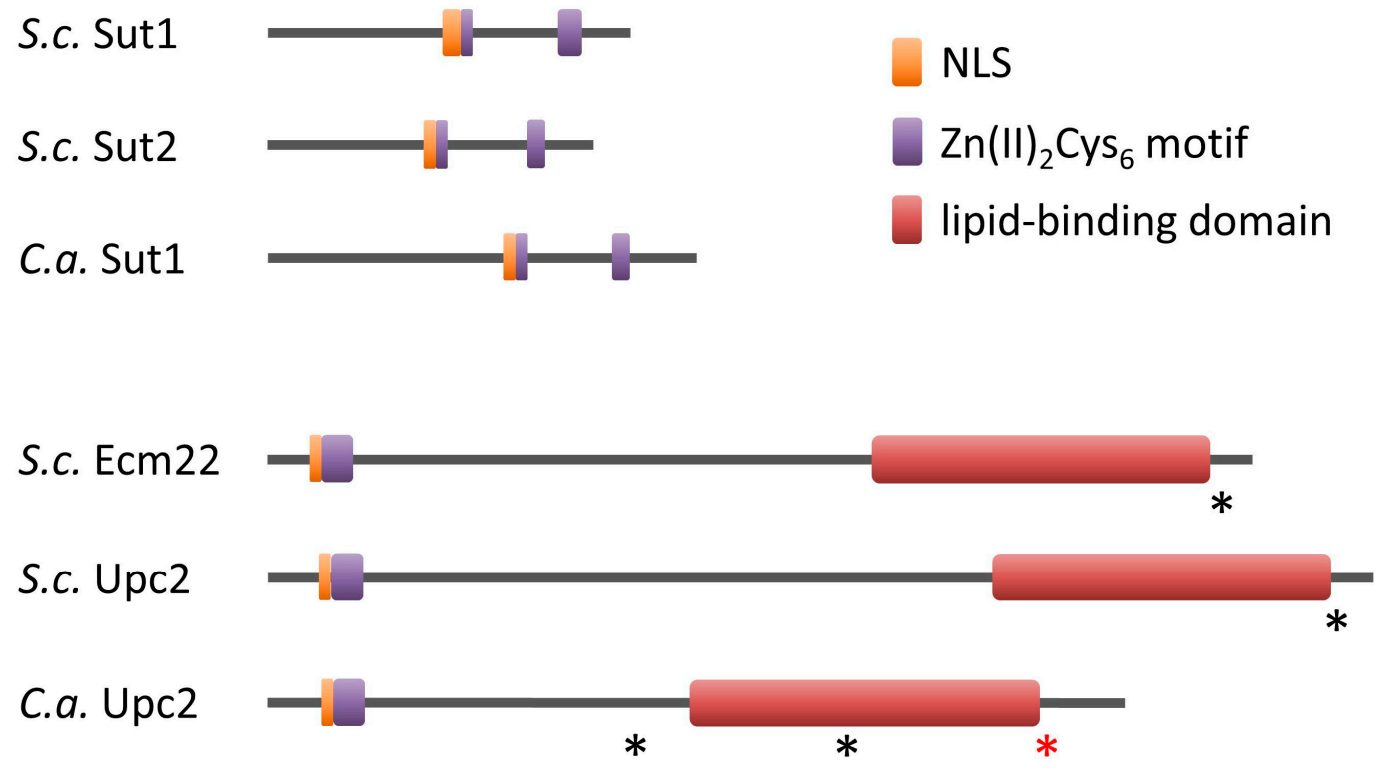

Figure 2. Domain structures of Ecm22, Upc2, Sut1 and Sut2. Shown are proteins from the budding yeast S. cerevisiae (S.c.) and C. albicans (C.a.). Asterisks denote gain-of-function mutations of Ecm 22 and Upc2. The red asterisk of $C$. albicans $U$ pc2 represents several distinct amino acid substitutions between residue 642 and 648 .

\section{Functions of Ecm22, Upc2, Sut1 and Sut2 in Budding Yeast}

\subsection{Regulation of Sterol Uptake}

The budding yeast Saccharomyces cerevisiae is one of the few eukaryotes that can grow rapidly under both aerobic and strictly anaerobic conditions [18]. Yeast cells adapt to a lack of oxygen by inducing the expression of "anaerobic genes". These genes encode for proteins that remodel sterol homeostasis, cell wall maintenance, respiration and carbohydrate metabolism.

Sterols are essential membrane lipids that are required for the structure and function of plasma membranes [19-21]. In fungi, the predominant sterol is ergosterol, the equivalent of mammalian cholesterol. In the presence of oxygen, yeast cells synthesize ergosterol and do not take up significant amounts of extracellular sterols [19]. This phenomenon, termed aerobic sterol exclusion, seems counterintuitive. Sterol biosynthesis is a complex process involving almost 30 enzymes and consumes large amounts of energy [21]. One may therefore expect that cells that are able to import sterols from the extracellular medium have a clear advantage. Aerobic exclusion might be a way for cells to ensure that only the best-fitting sterols accumulate in its membranes. In fact, cells with defects in the sterol biosynthesis pathway display pleiotropic defects such as impaired endocytosis, cell polarization, cell fusion and cell wall assembly [22-26]. Under anaerobic conditions, cells cannot synthesize ergosterol since this process requires oxygen, and cells import sterols, which are then required for viability [20]. Sut1, Sut2, Upc2 and Ecm22 all play important roles in the control of sterol uptake in the absence of oxygen.

Overexpression of either SUT1 or SUT2 induces sterol import, even under aerobic conditions $[8,10]$. However, the simultaneous deletion of SUT1 and SUT2 does not affect sterol import and growth under anaerobic conditions [10], presumably due to the presence of other regulators of sterol uptake such as Ecm22 and Upc2. The constitutively active mutant Upc2-1, in which glycine at position 888 near the C-terminus is altered to aspartic acid (G888D), also imports sterols in the presence of oxygen [7,9] (Figure 2). The C-terminal region containing the point mutation is highly similar between Ecm 22 and Upc2 [11] (Figure 2). Introduction of the corresponding point mutation in Ecm22 (G790D) also results in increased sterol uptake [11]. 
The hyperactive Upc2-1 upregulates the expression of AUS1 and PDR11, which encode two closely related members of the ATP-binding cassette (ABC) family of transporters [27]. Aus1 and Pdr11 form a complex in the plasma membrane and are together essential for sterol import [27-29]. DAN1 is another anaerobic gene whose expression is induced by Upc2 [27,30]. DAN1 encodes a cell wall mannoprotein that mediates sterol import $[27,31]$. It would be interesting to find out how cell wall proteins such as Dan1 and plasma membrane transporters such as Aus1 and Pdr11 function together in the uptake of sterols.

Little is known about the exact role of Ecm22 in sterol uptake. However, the anaerobic induction of DAN1 seems to depend on both Ecm22 and Upc2 [32]. Sut1 stimulates the expression of DAN1 and AUS1, like Upc2, but not of PDR11 [17,31,33]. The underlying mechanisms of Sut2-mediated sterol uptake are unknown. Concomitant overexpression of SUT1 and SUT2 results in the same sterol uptake levels as overexpression of either SUT1 or SUT2 alone, suggesting that Sut1 and Sut2 may control the expression of the same or very similar targets [10]. Rather few target genes have been identified for Sut2 and all of them are also regulated by Sut1 [34,35]. However, none of the Sut2 target genes seems to be involved in sterol uptake.

\subsection{General Adaptations to Anaerobic Conditions}

Switching from sterol synthesis to sterol uptake is not the only adaptation to anaerobic conditions. Yeast cells also alter the expression of genes involved in cell wall maintenance and respiration [18]. Upc2 and Sut1 play important roles in these processes but are not the only regulators. Interestingly, budding yeast does not sense oxygen concentrations directly. Instead, transcription factors sense the levels of molecules that require oxygen for their synthesis, such as heme and ergosterol [18]. In the presence of oxygen, heme is synthesized and binds to Hap1, a transcriptional regulator of the zinc cluster protein family. Activation of Hap 1 by heme induces the expression of aerobic genes including ROX1, which encodes a repressor of anaerobic genes. Rox1 binds to the promoter region of these genes often together with the general co-repressor Tup1-Cyc8 (also known as Tup1-Ssn6). Mot3, another DNA-binding protein, enhances Rox1 repression for some anaerobic genes. In the absence of oxygen, heme is no longer synthesized, which results in the deactivation of Hap1 and therefore reduced expression of ROX1. The loss of Rox1 repression then leads to activation of anaerobic genes. As described below, Rox1 also controls the transcription of UPC2 and SUT1.

Sut1 and Upc2 regulate the expression of anaerobic genes. Over 100 anaerobic genes have an Upc2-binding site in their promoter [36]. This includes all but one member of the PAU/DAN/TIR group. The DAN/TIR family includes DAN1, DAN4, TIP1 and TIR1-4. The related PAU family consists of 24 members including PAU23 and PAU24, which were previously named DAN2 and DAN3, respectively [37]. Expression of PAU/DAN/TIR genes is not or only partially controlled by Rox1 or Hap1 [30,36,38-41]. Upc2 and Sut1 both positively regulate the expression of over $10 P A U / D A N / T I R$ genes $[27,30,31,41]$. Rather little is known about these anaerobic proteins. Several of them are cell wall mannoproteins and seem to be involved in cell wall maintenance. As mentioned above, Dan1 mediates sterol uptake $[27,31]$. Complementation experiments in Candida glabrata using budding yeast TIR3 suggest that TIR3 might also have a role in sterol import [42]. There is no evidence that other $P A U / D A N / T I R$ genes are also involved in sterol uptake. Interestingly, Upc2 not only upregulates the expression of PAU/DAN/TIR genes under anaerobic conditions; at the same time, Upc2 downregulates CWP2, a major aerobic counterpart of the PAU/DAN/TIR group [43]. Thus, Upc2 reciprocally controls the transcription of aerobic and anaerobic cell wall genes in the absence of oxygen.

Only few anaerobic target genes have been identified for Ecm22. It appears that Ecm22 induces at least some PAU/DAN/TIR genes, including DAN1, PAU23 and PAU24 [32,43].

Sut1 is also involved in remodelling respiratory metabolism in the absence of oxygen. It downregulates the expression of several genes with mitochondrial functions, which lowers the respiratory rate [31]. 


\subsection{Control of Sterol Biosynthesis}

Upc2 and Ecm22 do not only mediate sterol uptake; they also control sterol biosynthesis. Regulation of sterol levels occurs through feedback mechanisms at the transcriptional and post-transcriptional levels [44]. Lower cellular sterol levels increase the expression of ERG genes, which encode the enzymes that catalyse ergosterol biosynthesis, whereas higher sterol levels reduce ERG transcription. In the lab, sterol depletion is often achieved by using sterol biosynthesis inhibitors such as statins and azoles. Statins block HMG-CoA reductase, which catalyses an early step in sterol biosynthesis. Azoles are important antifungals that inhibit the enzyme Erg11, which functions at a later stage of ergosterol biosynthesis. Treatment with these drugs triggers the upregulation of ERG genes. This induction requires both Ecm 22 and Upc2 [45]. Positive transcriptional regulation by Upc2 and Ecm 22 has been demonstrated for many ERG genes $[27,45,46]$. Cells that lack Ecm22 and Upc2 have a very different sterol profile [47]. Ergosterol levels are strongly reduced and several intermediates, particularly of the later stage of the biosynthetic pathway, are enriched compared to the wild type. As a consequence, an ECM22 UPC2 double deletion strain exhibits a much higher sensitivity to sterol biosynthesis inhibitors [45].

Interestingly, Upc2 also regulates the expression of ARE1, ATF2 and HES1, which play roles in various aspects of sterol homeostasis [27]. Are1 catalyses the formation of steryl ester, the storage form of ergosterol $[19,21]$. Atf2 catalyses sterol acetylation, which seems to be important for sterol detoxification [19,20]. Hes1 (also known as Osh5) has ill-defined roles in sterol homeostasis. It is probably involved in sterol synthesis and intracellular sterol transport $[48,49]$. Unfortunately, these potentially interesting links have not been characterized yet.

Sut1 probably does not have a major role in sterol synthesis. SUT1 overexpression has only a slight effect on the levels of sterol intermediates, but not of ergosterol [10]. Furthermore, expression of ERG genes is not regulated by Sut1 [31,35]. An involvement of Sut2 in sterol biosynthesis has not been reported.

In summary, Sut1, Sut2, Ecm22 and Upc2 all control sterol uptake in the absence of oxygen. Sut1 and Upc2 also regulate other adaptations to anaerobic conditions. Ecm 22 and Upc2 regulate sterol biosynthesis. Several targets genes are overlapping for Ecm22 and Upc2 in sterol biosynthesis, and for Sut1 and Upc2 for the adaptations to anaerobic conditions. Ecm22, Upc2, Sut1 and Sut2 are largely positive transcriptional regulators in these processes.

\section{Regulatory Mechanisms}

Interestingly, the regulatory mechanisms for the processes described above seem to be connected. Under optimal conditions some Ecm22 and Upc2 bind to ERG promoters, which is important for uninduced expression of ERG genes [45]. When sterol levels drop following treatment with sterol biosynthesis inhibitors, Ecm 22 is released from ERG promoters, a process that involves Mot3 [32,50]. At the same time, UPC2 expression is upregulated and binding of Upc2 to ERG promoters strongly increases, which results in ERG induction [50,51]. This increase in UPC2 expression can be explained by autoregulation. The UPC2 promoter contains Upc2-binding sites and positive control of its own transcription has been demonstrated for Upc2 [27,30,52].

Control of UPC2 transcription is an important regulatory mechanism for sterol biosynthesis. However, the recent determination of the structure of the C-terminal domain of Upc2 revealed an additional control mechanism [14]. The C-terminal region of Upc2 serves as a lipid-binding domain (Figure 2). When ergosterol is plentiful, this domain extracts sterol from the plasma membrane. This is a highly specific process. The lipid-binding domain can extract ergosterol and the related dehydroergosterol but not other sterols such as cholesterol. The lipid-binding domain is a novel fold not present in any other protein. Eleven $\alpha$ helices and connecting loops form a hydrophobic pocket for ergosterol in the core of the protein (Figure 3). The lipid-binding domain is also important for Upc2 dimerization as two $\alpha$ helices of each subunit form a hydrophobic dimer interface (Figure 3). Under sterol-rich conditions, Upc2 binds ergosterol and localizes predominantly to the cytoplasm, 
possibly because the lipid-binding domain masks the NLS [14] (Figure 4). When sterol levels drop, ergosterol dissociates from Upc2, which could result in a conformational change that exposes the NLS and allows the protein to translocate to the nucleus, where it induces expression of $E R G$ genes $[14,16]$. The analysis of the lipid-binding domain also provides a mechanism for the gain-of-function mutant UPC2-1 [9]. The G888D mutation lies near the lipid-binding domain and disrupts sterol binding [14] (Figure 2). The mutant protein can only be found in the nucleus, where it induces gene expression.

Ecm22 also possesses a lipid-binding domain that extracts sterols from membranes and translocates to the nucleus in response to sterol depletion [14,16]. Nevertheless, Ecm22 only seems to play a minor role in $E R G$ gene induction.

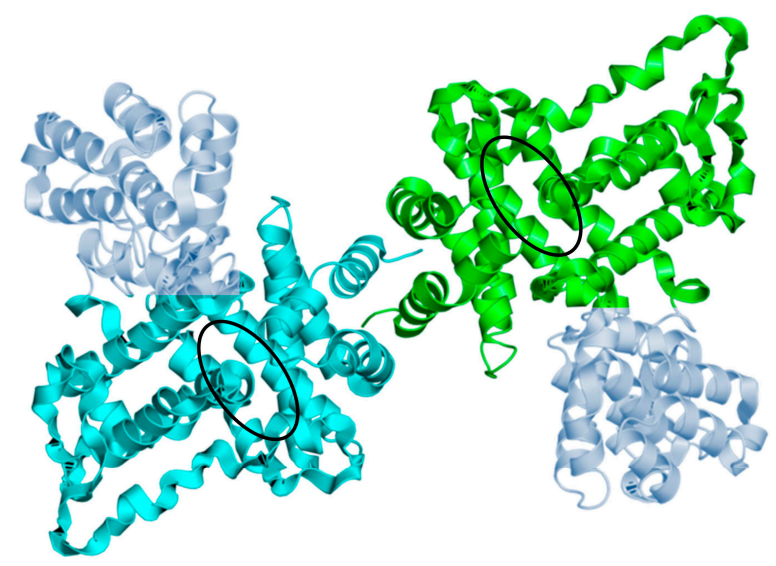

Figure 3. Crystal structure of the Upc2 lipid-binding domain. The lipid-binding domain forms dimers shown in green and turquoise (PDB 4N9N). To improve diffraction quality for crystallographic studies, a T4 lysozyme has been inserted between helix 5 and 6 (shown in light blue) [14]. The hydrophobic pockets are shown by the black ellipses.

A

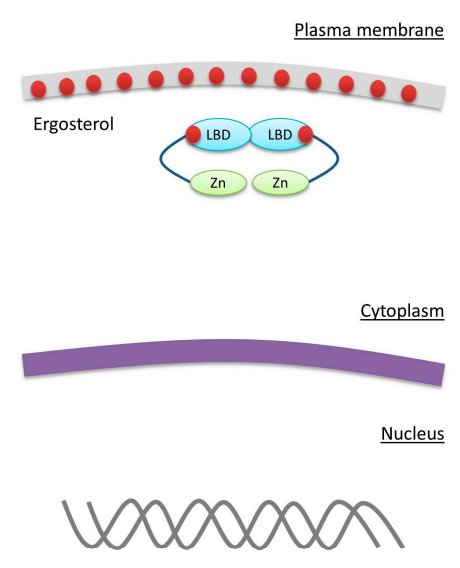

B
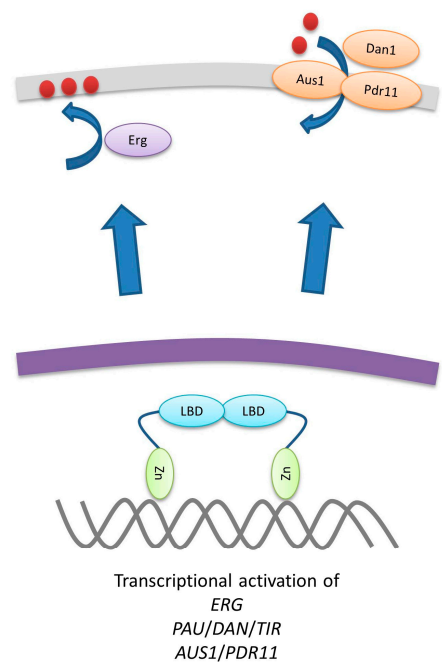

Figure 4. Regulation of Upc2 activity through lipid sensing. (A) When ergosterol (red spheres) levels are high it binds to the lipid-binding domain (LBD) of Upc2 and keeps the protein in the cytoplasm, possibly because the lipid-binding domain masks the NLS that lies adjacent to the $\mathrm{Zn}(\mathrm{II})_{2} \mathrm{Cys}_{6}$ motif (Figure 2) (Zn). (B) When sterol levels drop ergosterol no longer binds to Upc2. This might trigger a conformational change of the protein, which results in a translocation to the nucleus. In the nucleus Upc2 induces genes involved in sterol biosynthesis, sterol uptake and general adaptations to anaerobic conditions. 
The expression of $E R G$ genes in response to sterol depletion and the adaptation to anaerobic growth are regulated by Upc2 and Ecm22 through similar mechanisms. Sterols cannot be synthesized in the absence of oxygen. This reduction of sterol levels serves as the primary signal for the induction of several PAU/DAN/TIR genes by Upc2 and Ecm22 [32]. It therefore seems likely that Upc2 also translocates from the cytoplasm to the nucleus when oxygen levels drop. In addition, anaerobic genes are induced through increasing Upc2 protein levels. In the presence of oxygen, UPC2 is expressed but partially repressed by Rox1 [36] (Figure 5). Under anaerobic conditions, UPC2 expression increases due to the loss of Rox1 repression and autoregulation [27,30,32,36].

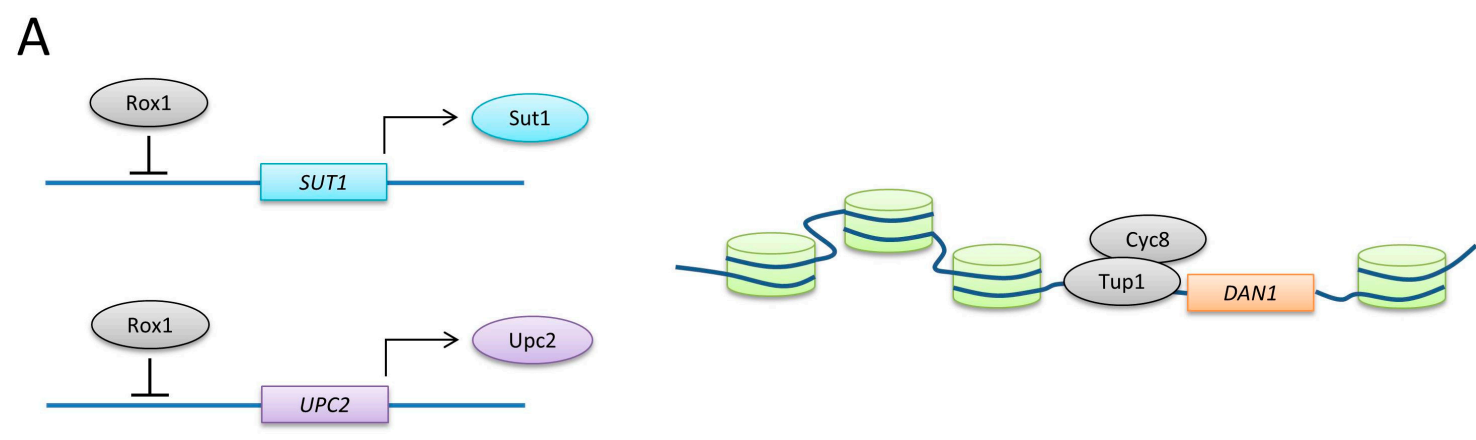

B

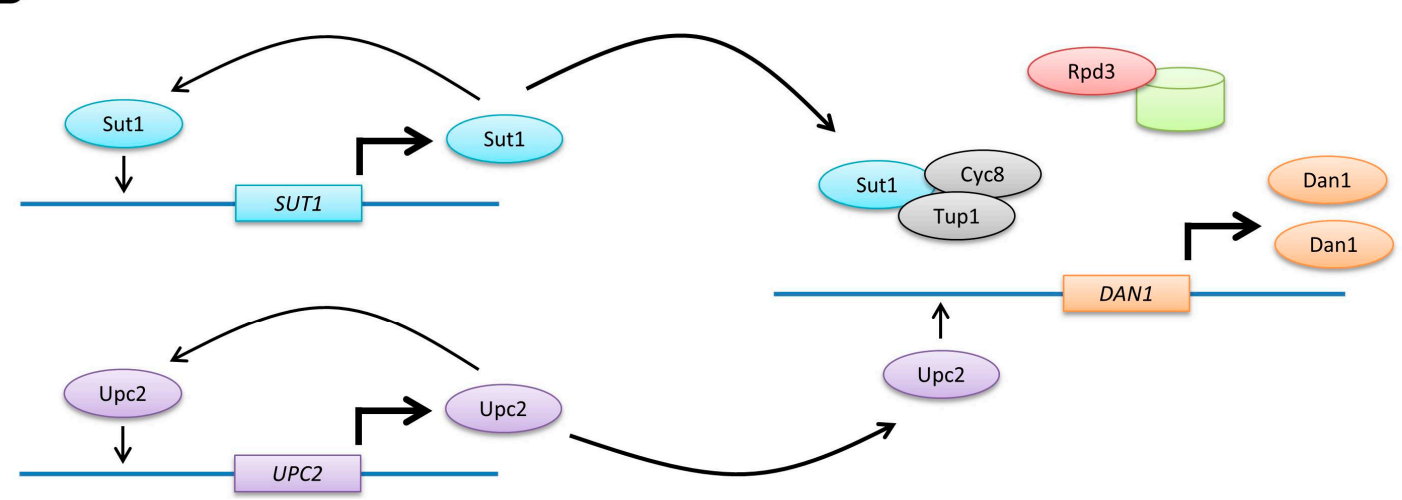

Figure 5. Transcriptional regulation of DAN1. (A) SUT1 and UPC2 are partially repressed by Rox1 in the presence of oxygen. The anaerobic gene DAN1 is not expressed due to chromatin-mediated repression. (B) Under anaerobic conditions, nucleosomes are released from the DAN1 promoter following histone deacetylation by Rpd3. Rox1 repression is lifted, which results in increased expression of UPC2 and SUT1. Upc2 induces DAN1 expression through direct binding with the promoter, whereas Sut1 might inactivate the co-repressor complex Cyc8-Tup1. Experiments that led to this model have largely been done with DAN1. However, these mechanisms might also apply to the regulation of other anaerobic genes.

The expression patterns of Sut1 and Upc2 are quite similar. Early Northern blotting experiments suggested that SUT1 is not expressed under aerobic conditions [8]. However, later real-time PCR and immunoblotting experiments showed that mRNA and protein are aerobically expressed and induced under anaerobic conditions, as suggested earlier $[8,34,53]$. Rox1 partially represses SUT1 in the presence of oxygen [8] (Figure 5). SUT1 expression is also autoregulated. Several Sut1 binding sites have been identified in the SUT1 promoter, and Sut1 positively regulates its own transcription [34,54].

SUT2 induction in response to the lack of oxygen has been reported, but the underlying regulatory mechanisms are unknown [55]. 
The anaerobic induction of $P A U / D A N / T I R$ by Upc2 requires the histone deacetylase Rpd3 [56]. An Rpd3 complex that includes Pho23, Sap30, Sds3, Sin3 and Ume1 targets the promoter of DAN1 and probably other $P A U / D A N / T I R$ genes. Following promoter binding under anaerobic conditions, Rpd3 deacetylates the $\mathrm{N}$-termini of histones $\mathrm{H} 3$ and $\mathrm{H} 4$. This results in the removal of nucleosomes from $D A N 1$, which is necessary for Upc2 binding to the DAN1 promoter (Figure 5).

Some of the $P A U / D A N / T I R$ genes and AUS1 are upregulated under anaerobic conditions by both Upc2 and Sut1 $[27,30,31,33]$. However, the mechanisms of transcriptional activation seem to be different. PAU/DAN/TIR genes, as well as AUS1 and PDR11, possess Upc2-binding sites in their promoters and Upc2 acts through these sites [27,30,36,57]. In contrast, it has been suggested that Sut1 does not bind directly to the DAN1 promoter [33]. Furthermore, a genome-wide screen that identified several Sut1 targets did not pick up any anaerobic genes [58], and no Sut1 binding site have been identified in the promoter regions of DAN1 and AUS1 [54,58]. Sut1 might act instead through the general co-repressor Tup1-Cyc8 [33]. Relieving this repression would result in increased transcription of DAN1 (Figure 5).

Sut1 is also regulated by the p21-activated kinases (PAKs) Ste20, Cla4 and Skm1 [17]. PAKs are important signalling molecules that are activated by the Rho GTPase Cdc42 [59]. PAKs can translocate to the nucleus, where they bind to Sut1 and downregulate the expression of AUS1 and DAN1 in a Sut1-dependent manner. This results in reduced sterol uptake [17]. Notably, PAKs also regulate sterol synthesis and storage, suggesting that the regulation of sterol homeostasis is important for functions of PAKs such as cell polarization, filamentation and hyperosmotic shock [60]. Such links have indeed been reported [22,24-26,35,61].

\section{Adaptations to Changing Environmental Conditions}

Sterol homeostasis is not only important for normal cell growth under aerobic and anaerobic conditions. Regulation of sterol biosynthesis also plays a critical role in the adaptation to changing environmental conditions. Sterol levels decrease, for example, in response to hyperosmotic stress but increase during filamentation $[35,61]$.

Hyperosmotic stress, which can be caused by high extracellular salt concentrations, triggers the high osmolarity glycerol (HOG) pathway [62]. Plasma membrane-bound receptors sense an increase in extracellular osmolarity, which leads to the activation of the mitogen-activated protein (MAP) kinase Hog1. Through phosphorylation of various substrates, Hog1 induces adaptations to hyperosmotic stress such as the synthesis of the osmolyte glycerol [62]. Activated Hog1 also increases the expression of MOT3 and, to a lesser extent, ROX1 [61]. Mot3 and Rox1 mediate the transcriptional repression of several ERG genes. These two repressors also lower ECM22 expression, which contributes to ERG repression as well. This downregulation of several $E R G$ genes results in reduced ergosterol levels. However, since some but not all ERG genes are repressed, sterol levels may not be simply lowered. It could be that the membrane sterol composition is modulated. While the alterations of the sterol profile seem to be an important adaptation to hyperosmotic stress, it is unfortunately not known how exactly cells are protected.

Ecm22 and Upc2 also positively regulate filamentation through increased sterol synthesis [35]. Filamentation occurs when cells grow on a semisolid medium with limited nutrients [63]. Under these conditions, cells become more elongated and do not separate following division. Furthermore, cells attach to and penetrate the medium they are growing on. Filamentous growth is therefore considered to represent a foraging mechanism. Ecm 22 and Upc2 are both required for filamentation [35]. Several $E R G$ genes are induced in an Ecm22- and Upc2-dependent manner when cells switch from the yeast form to the filamentous form. ERG genes seem to play a crucial role in this developmental transition since they are essential for filamentation. In addition, ERG expression is not only controlled by Ecm22 and Upc2 but also by Ste12, Phd1, Mga1 and Flo8, which are key transcriptional regulators of filamentation [64]. As a consequence, the ergosterol concentration increases during filamentation. 
Similar to the altered sterol levels in response to hyperosmotic stress, it remains unknown why exactly changes of sterol concentrations are required during filamentation.

Ecm22 and Upc2 not only control ERG genes but also upregulate FHN1, NPR1 and PRR2 expression during filamentation. FHN1, NPR1 and PRR2 play important roles in filamentous growth.

Sut 1 and Sut2 are also key regulators of filamentation but, in contrast to Ecm22 and Upc2, they inhibit filamentation $[15,34,35]$. GAT2, HAP4, MGA1, MSN4, NCE102, NPR1, PRR2, RHO3 and RHO5 have been identified as targets of both Sut1 and Sut2 [34,35,58,65]. All of them are either essential for filamentation or at least play an important role in this process $[34,35,66,67]$. The expression of these genes, with the exception of $M G A 1$, is upregulated when cells switch from the yeast form to the filamentous form $[34,35]$. The Sut1/Sut2 target genes seem to play a crucial role in filamentation because like ERG genes they also have binding sites for the filamentation master regulators Flo8, Mga1, Phd1, Ste12, Sok2 and Tec1 [64]. Sut1 and Sut2 partially repress the expression of GAT2, HAP4, MGA1, MSN4, NCE102, NPR1, PRR2, RHO3 and RHO5 when nutrients are plentiful [34,35,65]. When cells grow on a semisolid substratum with limited nutrients, this repression is lifted and results in an induction of the Sut1/Sut2 targets. Combined activity of the corresponding proteins might then trigger filamentation.

The mechanisms of transcriptional regulation by Sut1 seem to be different for filamentation and adaptation to anaerobic growth. It has been suggested that induction of DAN1 in the absence of oxygen is not achieved through direct interaction of Sut1 with DNA but rather through inactivation of the general co-repressor Tup1-Cyc8 [33]. In contrast, Sut1 binds directly to DNA to regulate the expression of targets involved in filamentation, and DNA-binding motifs have been identified for Sut1 [54,58].

Sut1, Sut2, Ecm 22 and Upc2 are regulated through a transcriptional network during filamentation (Figure 6). When cells sense nutrient deprivation and a semisolid substratum, the transcription factor Ste12 becomes activated [63]. Ste12 downregulates the expression of SUT1 and SUT2, which results in induction of Sut1/Sut2 targets [34,35]. Among these targets is UPC2, whose expression increases during filamentation [35]. This in turn leads to the upregulation of Upc2 targets (FHN1, NPR1, PRR2 and $E R G$ genes).

Sut1, Sut2, Ecm 22 and Upc2 also regulate mating. There are two distinct haploid cell types in budding yeast, termed a cells and $\alpha$ cells $[68,69]$. The two cell types secrete different pheromones to elicit a mating response in cells of the opposite cell type. Pheromone signalling triggers a $G_{1}$ arrest and formation of a mating projection, which is required for subsequent cell fusion. Sut1 and Sut2 play a positive role in mating [65], which is achieved through repression of NCE102, PRR2 and RHO5. The corresponding proteins have important roles in filamentation, as described above. They also inhibit mating and are therefore downregulated in response to pheromone treatment $[65,70]$. It therefore seems that Sut1 and Sut2 control the fate of a cell through the same set of genes. NCE102, PRR2 and $\mathrm{RHO} 5$ expression is upregulated under conditions that trigger filamentation due to the loss of Sut1/Sut2 repression. When cells are exposed to pheromones, transcription of NCE102, PRR2 and RHO5 is repressed, which allows cells to mate. We have recently found that Ecm22 and Upc2 also regulate mating by a mechanism that is independent of the regulation of NCE102, PRR2, RHO5 and ERG gene expression (T. Höfken, manuscript in preparation). 

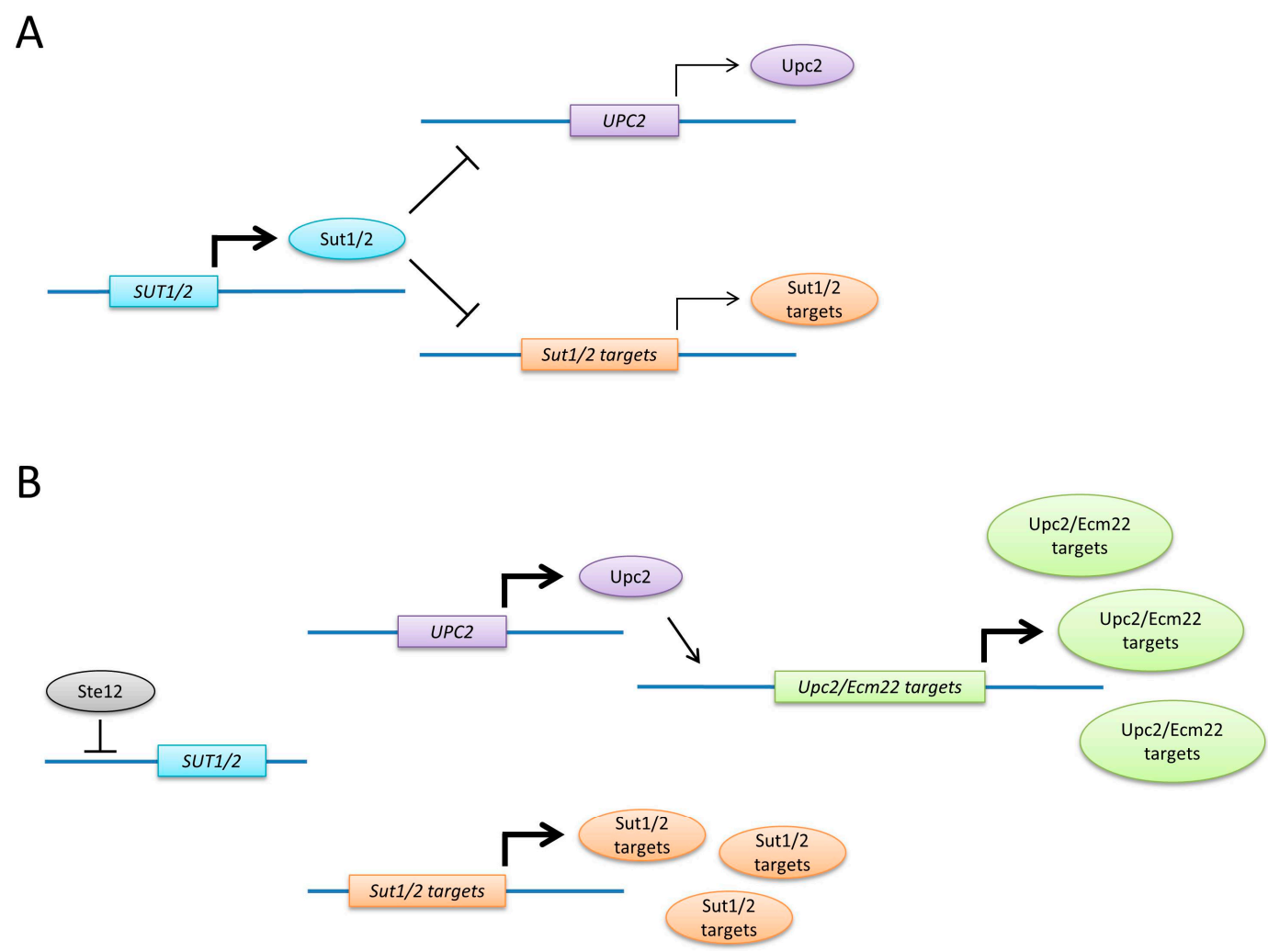

Figure 6. Transcriptional regulation of filamentation. (A) Under nutrient-rich conditions, SUT1 and SUT2 are expressed and partially repress UPC2 and target genes that have a role in filamentation; (B) when cells grow on a semisolid medium with limited nutrients, Ste12 becomes activated, which represses SUT1 and SUT2. This results in induction of the Sut1/Sut2 target genes including UPC2, which in turn leads to increased expression of Ecm22/Upc2 targets. The combined action of increased levels of Sut1/Sut2 and Ecm22/Upc2 targets might then trigger a switch to filamentous growth. Arrows indicate induction of gene expression, T-bars represent repression.

Taken together, Ecm22, Upc2, Sut1 and Sut2 all regulate cell fate decisions such as filamentation and mating. In contrast to sterol uptake and other adaptations to anaerobic growth, Ecm22, Upc2, Sut1 and Sut 2 control different sets of genes (with the exception of PRR2 and NPR1, which are regulated by all four zinc cluster proteins) and they also have opposing roles. Sut1 and Sut2 are negative regulators of filamentation, whereas Ecm22/Upc2 induces filamentous growth.

\section{Orthologs of ECM22, UPC2, SUT1 and SUT2 in Other Species}

Orthologs of ECM22, UPC2, SUT1 and SUT2 exist in other fungi. However, UPC2/ECM22 seem to be restricted to species of the Saccharomycotina, a lineage within the Ascomycetes [13]. The Saccharomycotina include the budding yeast $S$. cerevisiae and all Candida species such as $C$. albicans, C. glabrata, C. parapsilosis and C. tropicalis. In other fungi and higher eukaryotes, some functions of Ecm22 and Upc2, including regulation of sterol synthesis and uptake, and adaptation to low oxygen levels, are carried out by sterol regulatory element-binding proteins (SREBPs) [44,71]. Ecm22/Upc2 and Sut1/Sut2 are paralogous pairs that arose from a whole genome duplication of a common ancestor of budding yeast and C. glabrata [10-13]. The other species listed here are more distant relatives of budding yeast that did not undergo this duplication event. It is therefore not surprising that UPC2/ECM22 have two orthologs in C. glabrata but only one in C. albicans [72-74].

The existence of orthologs raises the question of whether the functions and molecular mechanisms of the corresponding proteins are the same in budding yeast and other species. Rewiring of gene regulatory networks is an important mechanism of evolutionary adaptation [75]. It has, for example, 
recently been shown that the zinc cluster protein Ppr1 regulates pyrimidine biosynthesis in budding yeast but allantoin catabolism in C. albicans [76]. Considering the very different environment budding yeast and Candida live in, major rewiring can be expected. Nevertheless, it seems that at least some processes, such as the regulation of sterol biosynthesis by Upc2, are relatively well conserved among the species described here. Upc2-binding sites can, for example, be found in most ERG genes of species of the Saccharomycotina lineage but not outside of this group [13]. Furthermore, the Upc2 lipid-binding domain is highly conserved among species of the Saccharomycotina, suggesting that these species sense sterol levels through the same mechanism [14].

\subsection{Upc2 and Sut1 in C. albicans}

C. albicans is an important human fungal pathogen $[77,78]$. It is a commensal that lives in the gastrointestinal and genitourinary tracts of healthy individuals. In immunocompromised patients, Candida cells can enter the bloodstream and invade virtually every tissue, which results in a very high mortality rate. These systemic $C$. albicans infections are usually treated with azoles, which inhibit Erg11, an enzyme of ergosterol biosynthesis. Since azoles are fungistatic and not funcicidal, cells can develop resistance, which is a clinical problem. UPC2, the sole ortholog of budding yeast UPC2 and ECM22 in C. albicans, is involved in azole resistance [72,73].

C. albicans Upc2 plays an important role in sterol biosynthesis. It directly binds to $E R G$ promoters and induces ERG transcription in response to sterol depletion [52,72,73,79]. UPC2 expression is also autoregulated [73,80,81]. Gain-of-function mutants of UPC2 have been identified in several azole-resistant clinical isolates [82-85]. Almost all of them encode amino acid substitutions in or near the lipid-binding domain of Upc2 (Figure 2). These mutations could prevent binding of ergosterol to the hydrophobic pocket and, as described for the G888D mutation of budding yeast Upc2, render the protein constitutively active in the nucleus [14]. The gain-of-function mutations cause increased expression of ERG11 and other ERG genes, which results in higher ergosterols levels and therefore reduced azole susceptibility [82-85].

Upc2 also positively regulates the expression of MDR1, which encodes a multidrug transporter of the major facilitator family that exports azoles $[79,82,85,86]$. Even though Upc2 seems to play a minor role in this process, it could contribute to azole resistance.

The gain-of-function mutations in Upc2 provide an advantage in the presence of azoles. At the same time, these mutants display decreased fitness, and as a consequence are also less virulent $[87,88]$. However, the role of UPC2 in virulence is not entirely clear. One study has reported that UPC2 deletion results in increased kidney colonization, whereas others have observed the opposite effect for the UPC2 deletion [88,89].

Upc2 plays a critical role in the adaptation to anaerobic conditions. Deletion of UPC2 has been reported to either be lethal or result in severely impaired growth in the absence of oxygen $[73,90]$. Furthermore, UPC2 expression is induced in response to anaerobic conditions $[79,80]$. Notably, hypoxia ( $1 \%$ oxygen) is one of the environmental signals that trigger filamentation in C. albicans. Hypoxia-induced filamentation requires UPC2, which is interesting because filamentation plays important roles in host cell adherence, tissue invasion and virulence $[78,91,92]$. It has also been reported that a UPC2 gain-of-function mutation reduces filamentation [88]. The role of UPC2 in this morphological switch is therefore not entirely clear.

The absence of UPC2 orthologs in humans, the role of Upc2 in azole resistance and potentially other important roles in Candida pathogenesis make Upc2 an interesting target for novel antifungal drugs [93].

Recently, a role for SUT1, the sole ortholog of budding yeast SUT1 and SUT2, has been established in C. albicans virulence [94]. A strain lacking SUT1 exhibits reduced kidney colonization and is defective in virulence. Sut1 is required for zinc acquisition, which is essential for infection. Sut1 regulates this process by inducing the expression of the transcription factor gene ZAP1. Zap1 in turn activates the expression of zinc acquisition genes. Interestingly, Upc2 binds directly to the SUT1 promoter and 
positively regulates SUT1 expression [79]. It would be interesting to further characterize this link and find out whether this constitutes a regulatory network of zinc cluster proteins during infection.

\subsection{UPC2 in Other Candida Species}

Other Candida species can also cause systemic infections [77]. C. glabrata is now emerging as a more common pathogen because it is less susceptible to azoles than $C$. albicans. The fact that $C$. glabrata can import sterols under aerobic conditions in response to sterol-containing serum and bile could be an explanation for its reduced azole sensitivity [95-97]. Serum also induces expression of several ERG genes. UPC2A and UPC2B, the two orthologs of budding yeast ECM22 and UPC2 have roles in sterol homeostasis $[74,98]$. They are both required for serum-induced sterol import. Upc2A upregulates the expression of several genes in this process including UPC2B and AUS1, the sole ortholog of budding AUS1 and PDR11 [74,98,99]. Expression of TIR3, the ortholog of budding yeast TIR3, is also induced by Upc2A [42]. The plasma membrane protein Aus1 and the cell wall protein Tir3 cooperate in sterol uptake $[42,99]$.

UPC2 orthologs also have important functions in azole resistance in C. parapsilosis and C. tropicalis [100-104]. UPC2 has been found to be upregulated and to contain mutations in azole-resistant clinical isolates. However, there are also important differences. The Upc2 mutations found in azole-resistant strains lie in the centre of the protein and not in or near the C-terminal of the lipid-binding domain of Upc2, as in C. albicans [103,104]. The effect of these mutations on the proteins is therefore not clear.

\section{Conclusions}

Initially, it seemed that cellular sterol homeostasis was the sole function of the zinc cluster proteins Ecm22, Sut1, Sut2 and Upc2. Homeostasis was achieved by regulating the transcription of sterol biosynthesis genes when sterol levels drop, and inducing the expression of sterol uptake genes in the absence of oxygen. More recently, it became evident that sterol levels need to be altered to cope with changing environmental conditions such as hyperosmotic stress. It was also found that Ecm22, Sut1, Sut2 and Upc2 have roles in other biological processes beyond sterol homeostasis such as mating and filamentation. More of these rather unexpected functions might be revealed in the future. Not surprisingly, much fundamental research has been done in budding yeast. However, since the importance of Upc2 and, to a lesser extent, Sut1, in Candida pathogenesis has become clearer, more research will probably focus on these proteins in Candida. Since zinc cluster proteins are fungal-specific, they are interesting targets for novel antifungals.

Acknowledgments: Research on zinc cluster proteins in our lab has been supported by a Deutsche Forschungsgemeinschaft (DFG) grant HO 2098/5 and a Brunel Research Initiative and Enterprise Fund (BRIEF) award to Thomas Höfken. The Brunel University London Open Access Publishing fund covered the costs to publish in open access.

Author Contributions: Ifeoluwapo Matthew Joshua and Thomas Höfken wrote the paper.

Conflicts of Interest: The authors declare no conflict of interest.

\section{References}

1. Todd, R.B.; Andrianopoulos, A. Evolution of a fungal regulatory gene family: The Zn(II)2Cys6 binuclear cluster DNA binding motif. Fungal Genet. Biol. 1997, 21, 388-405. [CrossRef] [PubMed]

2. MacPherson, S.; Larochelle, M.; Turcotte, B. A fungal family of transcriptional regulators: The zinc cluster proteins. Microbiol. Mol. Biol. Rev. 2006, 70, 583-604. [CrossRef] [PubMed]

3. Marmorstein, R.; Carey, M.; Ptashne, M.; Harrison, S.C. DNA recognition by GAL4: Structure of a protein-DNA complex. Nature 1992, 356, 408-414. [CrossRef] [PubMed]

4. Marmorstein, R.; Harrison, S.C. Crystal structure of a PPR1-DNA complex: DNA recognition by proteins containing a $\mathrm{Zn}_{2} \mathrm{Cys}_{6}$ binuclear cluster. Genes Dev. 1994, 8, 2504-2512. [CrossRef] [PubMed] 
5. Schjerling, P.; Holmberg, S. Comparative amino acid sequence analysis of the $C_{6}$ zinc cluster family of transcriptional regulators. Nucleic Acids Res. 1996, 24, 4599-4607. [CrossRef] [PubMed]

6. Reece, R.J.; Ptashne, M. Determinants of binding-site specificity among yeast $\mathrm{C}_{6}$ zinc cluster proteins. Science 1993, 261, 909-911. [CrossRef] [PubMed]

7. Lewis, T.L.; Keesler, G.A.; Fenner, G.P.; Parks, L.W. Pleiotropic mutations in Saccharomyces cerevisiae affecting sterol uptake and metabolism. Yeast 1988, 4, 93-106. [CrossRef] [PubMed]

8. Bourot, S.; Karst, F. Isolation and characterization of the Saccharomyces cerevisiae SUT1 gene involved in sterol uptake. Gene 1995, 165, 97-102. [CrossRef]

9. Crowley, J.H.; Leak, F.W., Jr.; Shianna, K.V.; Tove, S.; Parks, L.W. A mutation in a purported regulatory gene affects control of sterol uptake in Saccharomyces cerevisiae. J. Bacteriol. 1998, 180, 4177-4183. [PubMed]

10. Ness, F.; Bourot, S.; Régnacq, M.; Spagnoli, R.; Bergès, T.; Karst, F. SUT1 is a putative Zn[II ${ }_{2} \mathrm{Cys}_{6}$-transcription factor whose upregulation enhances both sterol uptake and synthesis in aerobically growing Saccharomyces cerevisiae cells. Eur. J. Biochem. 2001, 268, 1585-1595. [CrossRef] [PubMed]

11. Shianna, K.V.; Dotson, W.D.; Tove, S.; Parks, L.W. Identification of a UPC2 homolog in Saccharomyces cerevisiae and its involvement in aerobic sterol uptake. J. Bacteriol. 2001, 183, 830-834. [CrossRef] [PubMed]

12. Byrne, K.P.; Wolfe, K.H. The Yeast Gene Order Browser: Combining curated homology and syntenic context reveals gene fate in polyploid species. Genome Res. 2005, 15, 1456-1461. [CrossRef] [PubMed]

13. Maguire, S.L.; Wang, C.; Holland, L.M.; Brunel, F.; Neuvéglise, C.; Nicaud, J.M.; Zavrel, M.; White, T.C.; Wolfe, K.H.; Butler, G. Zinc finger transcription factors displaced SREBP proteins as the major Sterol regulators during Saccharomycotina evolution. PLoS Genet. 2014, 10, e1004076. [CrossRef] [PubMed]

14. Yang, H.; Tong, J.; Lee, C.W.; Ha, S.; Eom, S.H.; Im, Y.J. Structural mechanism of ergosterol regulation by fungal sterol transcription factor Upc2. Nat. Commun. 2015, 6, 6129. [CrossRef] [PubMed]

15. Rützler, M.; Reissaus, A.; Budzowska, M.; Bandlow, W. SUT2 is a novel multicopy suppressor of low activity of the cAMP/protein kinase A pathway in yeast. Eur. J. Biochem. 2004, 271, 1284-1291. [CrossRef] [PubMed]

16. Marie, C.; Leyde, S.; White, T.C. Cytoplasmic localization of sterol transcription factors Upc2p and Ecm22p in S. cerevisiae. Fungal Genet. Biol. 2008, 45, 1430-1438. [CrossRef] [PubMed]

17. Lin, M.; Unden, H.; Jacquier, N.; Schneiter, R.; Just, U.; Höfken, T. The Cdc42 effectors Ste20, Cla4, and Skm1 down-regulate the expression of genes involved in sterol uptake by a mitogen-activated protein kinase-independent pathway. Mol. Biol. Cell 2009, 20, 4826-4837. [CrossRef] [PubMed]

18. Trendeleva, T.A.; Aliverdieva, D.A.; Zvyagilskaya, R.A. Mechanisms of sensing and adaptive responses to low oxygen conditions in mammals and yeasts. Biochemistry 2014, 79, 750-760. [CrossRef] [PubMed]

19. Henneberry, A.L.; Sturley, S.L. Sterol homeostasis in the budding yeast, Saccharomyces cerevisiae. Semin. Cell Dev. Biol. 2005, 16, 155-161. [CrossRef] [PubMed]

20. Jacquier, N.; Schneiter, R. Mechanisms of sterol uptake and transport in yeast. J. Steroid Biochem. Mol. Biol. 2012, 129, 70-78. [CrossRef] [PubMed]

21. Klug, L.; Daum, G. Yeast lipid metabolism at a glance. FEMS Yeast Res. 2014, 14, 369-388. [CrossRef] [PubMed]

22. Bagnat, M.; Simons, K. Cell surface polarization during yeast mating. Proc. Natl. Acad. Sci. USA 2002, 99, 14183-14188. [CrossRef] [PubMed]

23. Heese-Peck, A.; Pichler, H.; Zanolari, B.; Watanabe, R.; Daum, G.; Riezman, H. Multiple functions of sterols in yeast endocytosis. Mol. Biol. Cell 2002, 13, 2664-2680. [CrossRef] [PubMed]

24. Tiedje, C.; Holland, D.G.; Just, U.; Höfken, T. Proteins involved in sterol synthesis interact with Ste20 and regulate cell polarity. J. Cell Sci. 2007, 120, 3613-3624. [CrossRef] [PubMed]

25. Jin, H.; McCaffery, J.M.; Grote, E. Ergosterol promotes pheromone signaling and plasma membrane fusion in mating yeast. J. Cell Biol. 2008, 180, 813-826. [CrossRef] [PubMed]

26. Aguilar, P.S.; Heiman, M.G.; Walther, T.C.; Engel, A.; Schwudke, D.; Gushwa, N.; Kurzchalia, T.; Walter, P. Structure of sterol aliphatic chains affects yeast cell shape and cell fusion during mating. Proc. Natl. Acad. Sci. USA 2010, 107, 4170-4175. [CrossRef] [PubMed]

27. Wilcox, L.J.; Balderes, D.A.; Wharton, B.; Tinkelenberg, A.H.; Rao, G.; Sturley, S.L. Transcriptional profiling identifies two members of the ATP-binding cassette transporter superfamily required for sterol uptake in yeast. J. Biol. Chem. 2002, 277, 32466-32472. [CrossRef] [PubMed] 
28. Li, Y.; Prinz, W.A. ATP-binding cassette (ABC) transporters mediate nonvesicular, raft-modulated sterol movement from the plasma membrane to the endoplasmic reticulum. J. Biol. Chem. 2004, 279, 45226-45234. [CrossRef] [PubMed]

29. Gulati, S.; Balderes, D.; Kim, C.; Guo, Z.A.; Wilcox, L.; Area-Gomez, E.; Snider, J.; Wolinski, H.; Stagljar, I.; Granato, J.T.; et al. ATP-binding cassette transporters and sterol $O$-acyltransferases interact at membrane microdomains to modulate sterol uptake and esterification. FASEB J. 2015, 29, 4682-4694. [CrossRef] [PubMed]

30. Abramova, N.E.; Cohen, B.D.; Sertil, O.; Kapoor, R.; Davies, K.J.; Lowry, C.V. Regulatory mechanisms controlling expression of the DAN/TIR mannoprotein genes during anaerobic remodeling of the cell wall in Saccharomyces cerevisiae. Genetics 2001, 157, 1169-1177. [PubMed]

31. Alimardani, P.; Régnacq, M.; Moreau-Vauzelle, C.; Ferreira, T.; Rossignol, T.; Blondin, B.; Bergès, T. SUT1-promoted sterol uptake involves the ABC transporter Aus1 and the mannoprotein Dan1 whose synergistic action is sufficient for this process. Biochem. J. 2004, 381, 195-202. [CrossRef] [PubMed]

32. Davies, B.S.; Rine, J. A role for sterol levels in oxygen sensing in Saccharomyces cerevisiae. Genetics 2006, 174, 191-201. [CrossRef] [PubMed]

33. Régnacq, M.; Alimardani, P.; El Moudni, B.; Bergès, T. Sut1p interaction with Cyc8p(Ssn6p) relieves hypoxic genes from Cyc8p-Tup1p repression in Saccharomyces cerevisiae. Mol. Microbiol. 2001, 40, 1085-1096. [CrossRef] [PubMed]

34. Foster, H.A.; Cui, M.; Naveenathayalan, A.; Unden, H.; Schwanbeck, R.; Höfken, T. The zinc cluster protein Sut1 contributes to filamentation in Saccharomyces cerevisiae. Eukaryot. Cell 2013, 12, 244-253. [CrossRef] [PubMed]

35. Woods, K.; Höfken, T. The zinc cluster proteins Upc2 and Ecm22 promote filamentation in Saccharomyces cerevisiae by sterol biosynthesis-dependent and -independent pathways. Mol. Microbiol. 2016, 99, 512-527. [CrossRef] [PubMed]

36. Kwast, K.E.; Lai, L.C.; Menda, N.; James, D.T., 3rd; Aref, S.; Burke, P.V. Genomic analyses of anaerobically induced genes in Saccharomyces cerevisiae: Functional roles of Rox1 and other factors in mediating the anoxic response. J. Bacteriol. 2002, 184, 250-265. [CrossRef] [PubMed]

37. Luo, Z.; van Vuuren, H.J. Functional analyses of PAU genes in Saccharomyces cerevisiae. Microbiology 2009, 155, 4036-4049. [CrossRef] [PubMed]

38. Sertil, O.; Cohen, B.D.; Davies, K.J.; Lowry, C.V. The DAN1 gene of S. cerevisiae is regulated in parallel with the hypoxic genes, but by a different mechanism. Gene 1997, 192, 199-205. [PubMed]

39. Rachidi, N.; Martinez, M.J.; Barre, P.; Blondin, B. Saccharomyces cerevisiae PAU genes are induced by anaerobiosis. Mol. Microbiol. 2000, 35, 1421-1430. [CrossRef] [PubMed]

40. Hickman, M.J.; Winston, F. Heme levels switch the function of Hap1 of Saccharomyces cerevisiae between transcriptional activator and transcriptional repressor. Mol. Cell. Biol. 2007, 27, 7414-7424. [CrossRef] [PubMed]

41. Hickman, M.J.; Spatt, D.; Winston, F. The Hog1 mitogen-activated protein kinase mediates a hypoxic response in Saccharomyces cerevisiae. Genetics 2011, 188, 325-338. [CrossRef] [PubMed]

42. Inukai, T.; Nagi, M.; Morita, A.; Tanabe, K.; Aoyama, T.; Miyazaki, Y.; Bard, M.; Nakayama, H. The mannoprotein TIR3 (CAGL0C03872g) is required for sterol uptake in Candida glabrata. Biochim. Biophys. Acta 2015, 1851, 141-151. [CrossRef] [PubMed]

43. Abramova, N.; Sertil, O.; Mehta, S.; Lowry, C.V. Reciprocal regulation of anaerobic and aerobic cell wall mannoprotein gene expression in Saccharomyces cerevisiae. J. Bacteriol. 2001, 183, 2881-2887. [CrossRef] [PubMed]

44. Espenshade, P.J.; Hughes, A.L. Regulation of sterol synthesis in eukaryotes. Annu. Rev. Genet. 2007, 41, 401-427. [CrossRef] [PubMed]

45. Vik, A.; Rine, J. Upc2p and Ecm22p, dual regulators of sterol biosynthesis in Saccharomyces cerevisiae. Mol. Cell. Biol. 2001, 21, 6395-6405. [CrossRef] [PubMed]

46. Germann, M.; Gallo, C.; Donahue, T.; Shirzadi, R.; Stukey, J.; Lang, S.; Ruckenstuhl, C.; Oliaro-Bosso, S.; McDonough, V.; Turnowsky, F.; et al. Characterizing sterol defect suppressors uncovers a novel transcriptional signaling pathway regulating zymosterol biosynthesis. J. Biol. Chem. 2005, 280, 35904-35913. [CrossRef] [PubMed] 
47. Valachovic, M.; Wilcox, L.I.; Sturley, S.L.; Bard, M. A mutation in sphingolipid synthesis suppresses defects in yeast ergosterol metabolism. Lipids 2004, 39, 747-752. [PubMed]

48. Beh, C.T.; Cool, L.; Phillips, J.; Rine, J. Overlapping functions of the yeast oxysterol-binding protein homologues. Genetics 2001, 157, 1117-1140. [PubMed]

49. Beh, C.T.; Rine, J. A role for yeast oxysterol-binding protein homologs in endocytosis and in the maintenance of intracellular sterol-lipid distribution. J. Cell Sci. 2004, 117, 2983-2996. [CrossRef] [PubMed]

50. Davies, B.S.; Wang, H.S.; Rine, J. Dual activators of the sterol biosynthetic pathway of Saccharomyces cerevisiae: Similar activation/regulatory domains but different response mechanisms. Mol. Cell. Biol. 2005, 25, 7375-7385. [CrossRef] [PubMed]

51. Hughes, T.R.; Marton, M.J.; Jones, A.R.; Roberts, C.J.; Stoughton, R.; Armour, C.D.; Bennett, H.A.; Coffey, E.; Dai, H.; He, Y.D.; et al. Functional discovery via a compendium of expression profiles. Cell 2000, 102, 109-126. [CrossRef]

52. Gallo-Ebert, C.; Donigan, M.; Liu, H.Y.; Pascual, F.; Manners, M.; Pandya, D.; Swanson, R.; Gallagher, D.; Chen, W.; Carman, G.M.; et al. The yeast anaerobic response element $\mathrm{AR} 1_{\mathrm{b}}$ regulates aerobic antifungal drug-dependent sterol gene expression. J. Biol. Chem. 2013, 288, 35466-35477. [CrossRef] [PubMed]

53. Ter Linde, J.J.; Liang, H.; Davis, R.W.; Steensma, H.Y.; van Dijken, J.P.; Pronk, J.T. Genome-wide transcriptional analysis of aerobic and anaerobic chemostat cultures of Saccharomyces cerevisiae. J. Bacteriol. 1999, 181, 7409-7413. [PubMed]

54. MacIsaac, K.D.; Wang, T.; Gordon, D.B.; Gifford, D.K.; Stormo, G.D.; Fraenkel, E. An improved map of conserved regulatory sites for Saccharomyces cerevisiae. BMC Bioinform. 2006, 7, 113. [CrossRef] [PubMed]

55. Lai, L.C.; Kosorukoff, A.L.; Burke, P.V.; Kwast, K.E. Metabolic-state-dependent remodeling of the transcriptome in response to anoxia and subsequent reoxygenation in Saccharomyces cerevisiae. Eukaryot. Cell 2006, 5, 1468-1489. [CrossRef] [PubMed]

56. Sertil, O.; Vemula, A.; Salmon, S.L.; Morse, R.H.; Lowry, C.V. Direct role for the Rpd3 complex in transcriptional induction of the anaerobic DAN/TIR genes in yeast. Mol. Cell. Biol. 2007, 27, 2037-2047. [CrossRef] [PubMed]

57. Cohen, B.D.; Sertil, O.; Abramova, N.E.; Davies, K.J.; Lowry, C.V. Induction and repression of DAN1 and the family of anaerobic mannoprotein genes in Saccharomyces cerevisiae occurs through a complex array of regulatory sites. Nucleic Acids Res. 2001, 29, 799-808. [CrossRef] [PubMed]

58. Harbison, C.T.; Gordon, D.B.; Lee, T.I.; Rinaldi, N.J.; Macisaac, K.D.; Danford, T.W.; Hannett, N.M.; Tagne, J.B.; Reynolds, D.B.; Yoo, J.; et al. Transcriptional regulatory code of a eukaryotic genome. Nature 2004, 431, 99-104. [CrossRef] [PubMed]

59. Boyce, K.J.; Andrianopoulos, A. Ste20-related kinases: Effectors of signaling and morphogenesis in fungi. Trends Microbiol. 2011, 19, 400-410. [CrossRef] [PubMed]

60. Lin, M.; Grillitsch, K.; Daum, G.; Just, U.; Höfken, T. Modulation of sterol homeostasis by the Cdc42p effectors Cla4p and Ste20p in the yeast Saccharomyces cerevisiae. FEBS J. 2009, 276, 7253-7264. [CrossRef] [PubMed]

61. Montañés, F.M.; Pascual-Ahuir, A.; Proft, M. Repression of ergosterol biosynthesis is essential for stress resistance and is mediated by the Hog1 MAP kinase and the Mot3 and Rox1 transcription factors. Mol. Microbiol. 2011, 79, 1008-1023. [CrossRef] [PubMed]

62. Saito, H.; Posas, F. Response to hyperosmotic stress. Genetics 2012, 192, 289-318. [CrossRef] [PubMed]

63. Cullen, P.J.; Sprague, G.F., Jr. The regulation of filamentous growth in yeast. Genetics 2012, 190, $23-49$. [CrossRef] [PubMed]

64. Borneman, A.R.; Leigh-Bell, J.A.; Yu, H.; Bertone, P.; Gerstein, M.; Snyder, M. Target hub proteins serve as master regulators of development in yeast. Genes Dev. 2016, 20, 435-448. [CrossRef] [PubMed]

65. Blanda, C.; Höfken, T. Regulation of mating in the budding yeast Saccharomyces cerevisiae by the zinc cluster proteins Sut1 and Sut2. Biochem. Biophys. Res. Commun. 2013, 438, 66-70. [CrossRef] [PubMed]

66. Lorenz, M.C.; Heitman, J. The MEP2 ammonium permease regulates pseudohyphal differentiation in Saccharomyces cerevisiae. EMBO J. 1998, 17, 1236-1247. [CrossRef] [PubMed]

67. Ryan, O.; Shapiro, R.S.; Kurat, C.F.; Mayhew, D.; Baryshnikova, A.; Chin, B.; Lin, Z.Y.; Cox, M.J.; Vizeacoumar, F.; Cheung, D.; et al. Global gene deletion analysis exploring yeast filamentous growth. Science 2012, 337, 1353-1356. [CrossRef] [PubMed] 
68. Alvaro, C.G.; Thorner, J. Heterotrimeric G Protein-coupled Receptor Signaling in Yeast Mating Pheromone Response. J. Biol. Chem. 2016, 291, 7788-7795. [CrossRef] [PubMed]

69. Atay, O.; Skotheim, J.M. Spatial and temporal signal processing and decision making by MAPK pathways. J. Cell Biol. 2017, 216, 317-330. [CrossRef] [PubMed]

70. Burchett, S.A.; Scott, A.; Errede, B.; Dohlman, H.G. Identification of novel pheromone-response regulators through systematic overexpression of 120 protein kinases in yeast. J. Biol. Chem. 2001, 276, 26472-26478. [CrossRef] [PubMed]

71. Butler, G. Hypoxia and gene expression in eukaryotic microbes. Annu. Rev. Microbiol. 2013, 67, $291-312$. [CrossRef] [PubMed]

72. Silver, P.M.; Oliver, B.G.; White, T.C. Role of Candida albicans transcription factor Upc2p in drug resistance and sterol metabolism. Eukaryot. Cell 2004, 3, 1391-1397. [CrossRef] [PubMed]

73. MacPherson, S.; Akache, B.; Weber, S.; de Deken, X.; Raymond, M.; Turcotte, B. Candida albicans zinc cluster protein Upc2p confers resistance to antifungal drugs and is an activator of ergosterol biosynthetic genes. Antimicrob. Agents Chemother. 2005, 49, 1745-1752. [CrossRef] [PubMed]

74. Nagi, M.; Nakayama, H.; Tanabe, K.; Bard, M.; Aoyama, T.; Okano, M.; Higashi, S.; Ueno, K.; Chibana, H.; Niimi, M.; et al. Transcription factors CgUPC2A and CgUPC2B regulate ergosterol biosynthetic genes in Candida glabrata. Genes Cells 2011, 16, 80-89. [CrossRef] [PubMed]

75. Nocedal, I.; Johnson, A.D. How Transcription Networks Evolve and Produce Biological Novelty. Cold Spring Harb. Symp. Quant. Biol. 2015, 80, 265-274. [CrossRef] [PubMed]

76. Tebung, W.A.; Choudhury, B.I.; Tebbji, F.; Morschhäuser, J.; Whiteway, M. Rewiring of the Ppr1 Zinc Cluster Transcription Factor from Purine Catabolism to Pyrimidine Biogenesis in the Saccharomycetaceae. Curr. Biol. 2016, 26, 1677-1687. [CrossRef] [PubMed]

77. Pfaller, M.A.; Diekema, D.J. Epidemiology of invasive candidiasis: A persistent public health problem. Clin. Microbiol. Rev. 2007, 20, 133-163. [CrossRef] [PubMed]

78. Höfken, T. Candida and candidiasis. In Microbial Pathogenesis; Kishore, U., Nayak, A., Eds.; Springer: New York, NY, USA, 2013; pp. 82-114.

79. Znaidi, S.; Weber, S.; Al-Abdin, O.Z.; Bomme, P.; Saidane, S.; Drouin, S.; Lemieux, S.; de Deken, X.; Robert, F.; Raymond, M. Genomewide location analysis of Candida albicans Upc2p, a regulator of sterol metabolism and azole drug resistance. Eukaryot. Cell 2008, 7, 836-847. [CrossRef] [PubMed]

80. Hoot, S.J.; Oliver, B.G.; White, T.C. Candida albicans UPC2 is transcriptionally induced in response to antifungal drugs and anaerobicity through Upc2p-dependent and -independent mechanisms. Microbiology 2008, 154, 2748-2756. [CrossRef] [PubMed]

81. Hoot, S.J.; Brown, R.P.; Oliver, B.G.; White, T.C. The UPC2 promoter in Candida albicans contains two cis-acting elements that bind directly to Upc2p, resulting in transcriptional autoregulation. Eukaryot. Cell 2010, 9, 1354-1362. [CrossRef] [PubMed]

82. Dunkel, N.; Liu, T.T.; Barker, K.S.; Homayouni, R.; Morschhäuser, J.; Rogers, P.D. A gain-of-function mutation in the transcription factor Upc2p causes upregulation of ergosterol biosynthesis genes and increased fluconazole resistance in a clinical Candida albicans isolate. Eukaryot. Cell 2008, 7, 1180-1190. [CrossRef] [PubMed]

83. Heilmann, C.J.; Schneider, S.; Barker, K.S.; Rogers, P.D.; Morschhäuser, J. An A643T mutation in the transcription factor Upc2p causes constitutive ERG11 upregulation and increased fluconazole resistance in Candida albicans. Antimicrob. Agents Chemother. 2010, 54, 353-359. [CrossRef] [PubMed]

84. Hoot, S.J.; Smith, A.R.; Brown, R.P.; White, T.C. An A643V amino acid substitution in Upc2p contributes to azole resistance in well-characterized clinical isolates of Candida albicans. Antimicrob. Agents Chemother. 2011, 55, 940-942. [CrossRef] [PubMed]

85. Flowers, S.A.; Barker, K.S.; Berkow, E.L.; Toner, G.; Chadwick, S.G.; Gygax, S.E.; Morschhäuser, J.; Rogers, P.D. Gain-of-function mutations in UPC2 are a frequent cause of ERG11 upregulation in azole-resistant clinical isolates of Candida albicans. Eukaryot. Cell 2012, 11, 1289-1299. [CrossRef] [PubMed]

86. Synnott, J.M.; Guida, A.; Mulhern-Haughey, S.; Higgins, D.G.; Butler, G. Regulation of the hypoxic response in Candida albicans. Eukaryot. Cell 2010, 9, 1734-1746. [CrossRef] [PubMed]

87. Sasse, C.; Dunkel, N.; Schäfer, T.; Schneider, S.; Dierolf, F.; Ohlsen, K.; Morschhäuser, J. The stepwise acquisition of fluconazole resistance mutations causes a gradual loss of fitness in Candida albicans. Mol. Microbiol. 2012, 86, 539-556. [CrossRef] [PubMed] 
88. Lohberger, A.; Coste, A.T.; Sanglard, D. Distinct roles of Candida albicans drug resistance transcription factors TAC1, MRR1, and UPC2 in virulence. Eukaryot. Cell 2014, 13, 127-142. [CrossRef] [PubMed]

89. Vandeputte, P.; Ischer, F.; Sanglard, D.; Coste, A.T. In vivo systematic analysis of Candida albicans Zn2-Cys6 transcription factors mutants for mice organ colonization. PLoS ONE 2011, 6, e26962. [CrossRef] [PubMed]

90. Zavrel, M.; Hoot, S.J.; White, T.C. Comparison of sterol import under aerobic and anaerobic conditions in three fungal species, Candida albicans, Candida glabrata, and Saccharomyces cerevisiae. Eukaryot. Cell 2013, 12, 725-738. [CrossRef] [PubMed]

91. Sudbery, P.E. Growth of Candida albicans hyphae. Nat. Rev. Microbiol. 2011, 9, 737-748. [CrossRef] [PubMed]

92. Gow, N.A.; van de Veerdonk, F.L.; Brown, A.J.; Netea, M.G. Candida albicans morphogenesis and host defence: Discriminating invasion from colonization. Nat. Rev. Microbiol. 2011, 10, 112-122. [CrossRef] [PubMed]

93. Gallo-Ebert, C.; Donigan, M.; Stroke, I.L.; Swanson, R.N.; Manners, M.T.; Francisco, J.; Toner, G.; Gallagher, D.; Huang, C.Y.; Gygax, S.E.; et al. Novel antifungal drug discovery based on targeting pathways regulating the fungus-conserved Upc2 transcription factor. Antimicrob. Agents Chemother. 2014, 58, 258-266. [CrossRef] [PubMed]

94. Xu, W.; Solis, N.V.; Ehrlich, R.L.; Woolford, C.A.; Filler, S.G.; Mitchell, A.P. Activation and alliance of regulatory pathways in C. albicans during mammalian infection. PLoS Biol. 2015, 13, e1002076. [CrossRef]

95. Nakayama, H.; Izuta, M.; Nakayama, N.; Arisawa, M.; Aoki, Y. Depletion of the squalene synthase (ERG9) gene does not impair growth of Candida glabrata in mice. Antimicrob. Agents Chemother. 2000, 44, 2411-2418. [CrossRef] [PubMed]

96. Bard, M.; Sturm, A.M.; Pierson, C.A.; Brown, S.; Rogers, K.M.; Nabinger, S.; Eckstein, J.; Barbuch, R.; Lees, N.D.; Howell, S.A.; et al. Sterol uptake in Candida glabrata: Rescue of sterol auxotrophic strains. Diagn. Microbiol. Infect. Dis. 2005, 52, 285-293. [CrossRef] [PubMed]

97. Nagi, M.; Tanabe, K.; Nakayama, H.; Yamagoe, S.; Umeyama, T.; Oura, T.; Ohno, H.; Kajiwara, S.; Miyazaki, Y. Serum cholesterol promotes the growth of Candida glabrata in the presence of fluconazole. J. Infect. Chemother. 2013, 19, 138-143. [CrossRef] [PubMed]

98. Whaley, S.G.; Caudle, K.E.; Vermitsky, J.P.; Chadwick, S.G.; Toner, G.; Barker, K.S.; Gygax, S.E.; Rogers, P.D. UPC2A is required for high-level azole antifungal resistance in Candida glabrata. Antimicrob. Agents Chemother. 2014, 58, 4543-4554. [CrossRef] [PubMed]

99. Nakayama, H.; Tanabe, K.; Bard, M.; Hodgson, W.; Wu, S.; Takemori, D.; Aoyama, T.; Kumaraswami, N.S.; Metzler, L.; Takano, Y.; et al. The Candida glabrata putative sterol transporter gene CgAUS1 protects cells against azoles in the presence of serum. J. Antimicrob. Chemother. 2007, 60, 1264-1272. [CrossRef] [PubMed]

100. Silva, A.P.; Miranda, I.M.; Guida, A.; Synnott, J.; Rocha, R.; Silva, R.; Amorim, A.; Pina-Vaz, C.; Butler, G.; Rodrigues, A.G. Transcriptional profiling of azole-resistant Candida parapsilosis strains. Antimicrob. Agents Chemother. 2011, 55, 3546-3556. [CrossRef] [PubMed]

101. Guida, A.; Lindstädt, C.; Maguire, S.L.; Ding, C.; Higgins, D.G.; Corton, N.J.; Berriman, M.; Butler, G. Using RNA-seq to determine the transcriptional landscape and the hypoxic response of the pathogenic yeast Candida parapsilosis. BMC Genom. 2011, 12, 628. [CrossRef] [PubMed]

102. Berkow, E.L.; Manigaba, K.; Parker, J.E.; Barker, K.S.; Kelly, S.L.; Rogers, P.D. Multidrug Transporters and Alterations in Sterol Biosynthesis Contribute to Azole Antifungal Resistance in Candida parapsilosis. Antimicrob. Agents Chemother. 2015, 59, 5942-5950. [CrossRef] [PubMed]

103. Choi, M.J.; Won, E.J.; Shin, J.H.; Kim, S.H.; Lee, W.G.; Kim, M.N.; Lee, K.; Shin, M.G.; Suh, S.P.; Ryang, D.W.; et al. Resistance Mechanisms and Clinical Features of Fluconazole-Nonsusceptible Candida tropicalis Isolates Compared with Fluconazole-Less-Susceptible Isolates. Antimicrob. Agents Chemother. 2016, 60, 3653-3661. [CrossRef] [PubMed]

104. Jiang, C.; Ni, Q.; Dong, D.; Zhang, L.; Li, Z.; Tian, Y.; Peng, Y. The Role of UPC2 Gene in Azole-Resistant Candida tropicalis. Mycopathologia 2016, 181, 833-838. [CrossRef] [PubMed]

(C) 2017 by the authors. Licensee MDPI, Basel, Switzerland. This article is an open access article distributed under the terms and conditions of the Creative Commons Attribution (CC BY) license (http:/ / creativecommons.org/licenses/by/4.0/). 